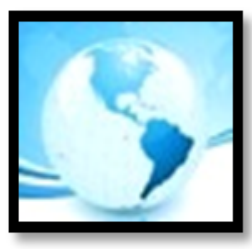

MALAYSIAN ONLINE JOURNAL OF

EDUCATIONAL MANAGEMENT

(MOJEM)

April 2018, VOLUME 6, ISSUE 2, 67 - 82

E-ISSN NO: $2289-4489$

https://doi.org/10.22452/mojem.vol6no2.4

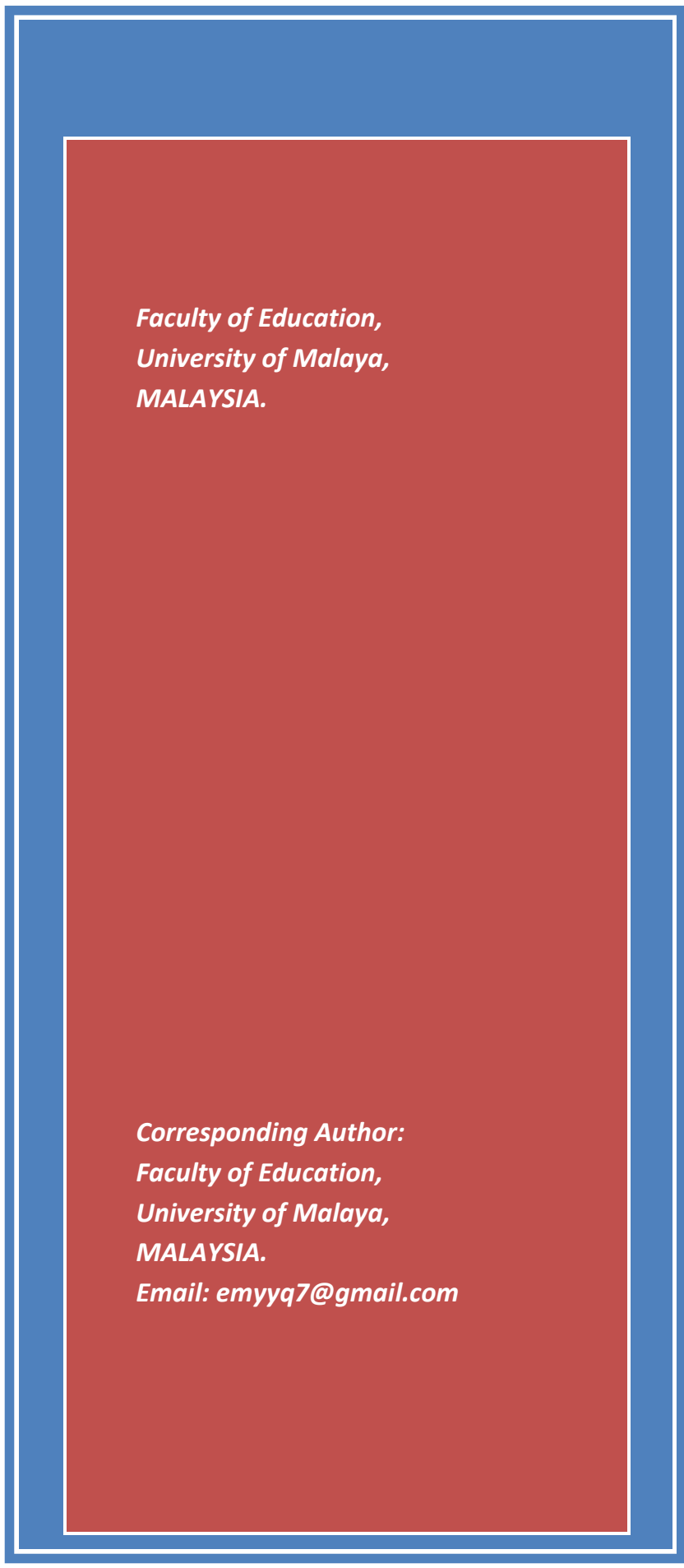

\title{
EXPLORING ISSUES ON TEACHING AND LEARNING IN MALAYSIAN PRIVATE PRESCHOOLS
}

Tee Ying Qin \& Mariani Md Nor (PhD)

\begin{abstract}
The Malaysian government, as with the rest of the world is becoming increasingly aware of the importance of early childhood education towards nation building. This involves constant monitoring on the quality of preschool education. To improve the Malaysian preschool system, it is crucial to identify the issues encountered in the preschool teaching and learning in actual practice. Hence, this study aimed to explore the issues regarding teaching and learning in Malaysian private preschool settings. Three in-service preschool teachers from the Klang Valley were selected through purposive sampling. Data was collected through open-ended interviews. Observation was also carried out to triangulate the survey findings. Thematic analysis of the findings then resulted in four themes and eight sub-themes. Findings indicated the structured and formal preschool environment with excessive emphasis on academic outcomes, which contradict the established principles of developmentally appropriate practice (DAP) as well as requirements in the national preschool curriculum. Mismatch between teachers' beliefs of the ideal practice and the actual practice was also discerned. Recommendations for stakeholders were included to tackle the identified issues towards developing a more conducive environment for the optimal development of Malaysian pre-schoolers. This present study will benefit policymakers, curriculum developers and relevant authorities related to early childhood education to catch a glimpse of the actual practice in many private preschools in Malaysia. Most importantly, it is hoped that this study would be a platform for a revamp in the Malaysian preschool education towards a more effective and holistic education for all Malaysian pre-schoolers.
\end{abstract}

Keywords: Teaching \& learning, Preschool education, Curriculum, Malaysia. 


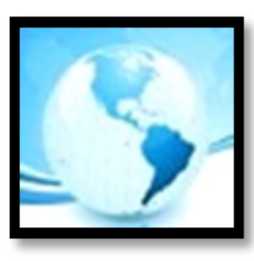

\section{MALAYSIAN ONLINE JOURNAL OF EDUCATIONAL MANAGEMENT (MOJEM)}

\section{INTRODUCTION}

Today, early childhood education has been regarded as of paramount importance across the globe by governments, policymakers and societies alike. It is however, difficult to determine the quality of service that each early childhood institution provides (Whitebread, Basilio, Kuvalja, \& Verma, 2012). The way an early childhood setting conducts its daily teaching and learning is one of the key determinants and a clear indicator of its quality.

Which teaching and learning approach is considered most appropriate for young children who are rapidly developing in all aspects? A myriad of research evidence had documented that play is the most effective pedagogy for teaching and learning for young children at their early childhood (Cheng, 2012; Kuschner, 2012; Loizou \& Avgitidou, 2014; Samuelsson \& Carlsson, 2008). Moreover, pre-schoolers who are at their golden age of development should be provided with ample opportunities for active, hands-on exploration and multisensory experiences instead of passive, teacher-directed rote learning which is considered inappropriate and obsolete in this present $21^{\text {st }}$ century.

However, research evidence established that global emphasis on pre-schooler's academic attainment especially the 3R's i.e. writing, reading and arithmetic has resulted in increasingly academic-inclined and formal preschool curriculum with limited time for fun, meaningful explorations for preschool children (Fisher, Hirsh-Pasek, Golinkoff, \& Gryfe, 2008; Huisman, Catapano, Moody, \& Gates, 2013; Milteer \& Ginsburg, 2012; Nicolopoulou, 2010; Nicolopoulou, Barbosa de Sá, Ilgaz, \& Brockmeyer, 2009; Sandberg \& Heden, 2011; Van Oers \& Duijkers, 2013).

In the Malaysian context, a significant amount of effort and initiatives had been implemented to improve and coordinate the pre-primary education in the nation $(\mathrm{Ng}, 2010 ;$ Majzub, 2013). The Malaysian Educational Blueprint has recently established that the nation is currently working towards $100 \%$ enrolment for all levels including early education (Ministry of Education, 2013). In preparation for the consistently increasing number of children attending preschools, the quality of the preschool curriculum has to be maintained at the highest level. This is to ensure that the children gain the utmost benefit in this key stage of their lives in order to build a strong human capital for the nation in the near future.

Despite various initiatives to restructure preschool education, available research evidences reveal that formal approach is still being used widely in many Malaysian preschools as the main medium for teaching and learning (e.g. Ali \& Mahamod, 2015; Abu Bakar, Daud, Nordin, \& Abdullah, 2015). In contrast with the ideal learning environment for preschool children which should be child-directed and involve active learning; rote learning, memorization and "chalk and talk" approaches are believed to be still in use in a significant amount of Malaysian preschool settings.

According to the Performance Management and Delivery Unit, also known as PEMANDU (2013), an astonishing percentage as high as $93 \%$ of preschool teachers have not undergone any formal training. These preschool teachers are mainly from the private sector that lacks monitoring and control in terms of teacher employment. Without adequate training, their competence in implementing developmentally appropriate practice for children's optimal development is largely questionable. Although every Malaysian preschool should adhere to the national preschool curriculum, each private preschool setting has its own philosophy. The extent to which each preschool adheres to and implements the National Preschool Curriculum Standard (NPCS) is also uncertain. In fact, Ng (2010) noted that most private preschools do not adhere to the guidelines established in the NPCS in practice. Hence in this study, the researcher has chosen to focus and explore teaching and learning issues specifically in Malaysian private preschools catered for young children from the age of four to six.

Nevertheless, this could not be generalised due to the incoherence of the Malaysian preschool system which is divided into its public and private sectors. In addition, based on literature reviews conducted by the researcher, it was discerned that there remain massive research gaps in the field of Malaysian early childhood education. 


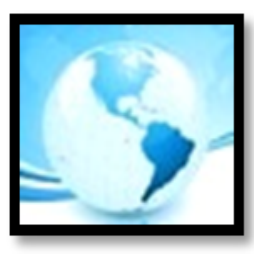

\section{MALAYSIAN ONLINE JOURNAL OF EDUCATIONAL MANAGEMENT (MOJEM)}

As research and practice should go hand in hand, the rigour of research on a specific field is among the factors for its growth and advancement. Despite the importance of this field, there has been insufficient attention and focus in terms of research in this context to strengthen the links between theory and practice. With insufficient solid empirical evidence as support, it is almost impossible for policy makers as well as preschool stakeholders to move forward toward establishing more efforts on reshaping the preschool education in Malaysia.

Therefore, there is an urgent need for this study, which aimed to explore the specific issues on teaching and learning in Malaysian private preschools. This will help policy makers to better understand the private preschool sector and hence help in devising appropriate initiatives to standardize preschool education in Malaysia. In addition, this present study aspires to contribute and add unto the body of literature regarding Malaysian early childhood education. It is also hoped that this study will act as a catalyst, leading to more studies about preschool education in Malaysia, hence establishing a comprehensive body of research to better inform the Malaysian preschool practice.

\section{The Malaysian Early Childhood Care and Education (ECCE)}

This section provides a general overview of early childhood education in Malaysia. The Malaysian government is becoming increasingly aware of the prime importance of early childhood education towards the nation's development (Ng, 2010; UNICEF, 2011). Various initiatives and effort have been planned and implemented to revamp and coordinate the pre-primary education in Malaysia ( $\mathrm{Ng}, 2010$; Majzub, 2013). The Malaysian government has also prioritized the idea of raising the quality of preschool education in the recent Government Transformation Programme (PEMANDU, 2015).

The current ECCE provision is divided into two categories, childcare centres (TASKA) for the 0 - 4-year olds and preschools (TADIKA) for 4-6 years old children (Curriculum Development Centre, 2008; Ng, 2010). The former is under the purview of the Ministry of Women, Family and Community; whilst the latter is placed under the joint coordination of Ministry of Rural and Regional Development (KEMAS), Department of National Unity and Integration (JPNIN) and Ministry of Education (MOE). Besides public early childhood programmes established by government bodies, there are also large numbers of privately owned nurseries and preschools.

Preschool enrolment in Malaysia is not compulsory till the school entry age at seven. The most recent statistics from the Performance Management and Delivery Unit (PEMANDU, 2015) indicated that Malaysian preschool enrolment rate has escalated to $84.26 \%$ at the end of 2014 , compared to $77 \%$ as of June 2011 (Ministry of Education, 2013). The Malaysia Education Blueprint has established that the nation is working towards $100 \%$ enrolment for all levels including early education (Ministry of Education, 2013). In preparation for the consistently increasing amounts of children attending preschools, the quality of our preschool curriculum should be maintained to ensure that children gain the utmost benefit at the key stage of their lives, in order to build a strong human capital for the nation in the near future.

Through the Education Act 1996 (2006), preschool education has been included under the national education system. It also establishes that all preschools, regardless of their types, whether private or government-owned are required to adhere to the national statutory preschool curriculum, i.e. the National Preschool Standard-based Curriculum (NPSC). The NPSC is the current Malaysian preschool curriculum in use since its first enforcement in 2010. The curriculum has been revised in 2016 in tandem with the recent Malaysia Education Blueprint 2013-2025 (Ministry of Education, 2013) and current needs. The aim of the NPSC is to develop pre-schoolers' potential in a comprehensive way across all developmental aspects including physical, spiritual, social and intellectual, "through safe and conducive learning environment, and fun, creative and meaningful activities" (Ministry of Education, 2017, p. 2). This is in line with the National Education Philosophy which aims to produce holistic individuals for the improvement of society and country (Ministry of Education, 2013). 


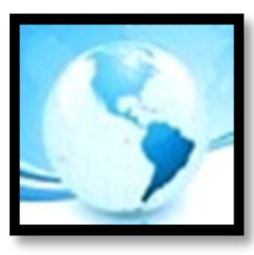

\section{MALAYSIAN ONLINE JOURNAL OF EDUCATIONAL MANAGEMENT (MOJEM)}

In the NPSC, the "learning through play" approach is established as an effective teaching and learning approach for meaningful early learning experiences (Ministry of Education, 2017). This is in accordance to constructivist learning theories whereby learners construct meaning based on first-hand interaction through play as they learn and develop in a holistic manner. Piaget and Vygotsky were notable constructivists who contributed significantly on the knowledge about how play enhances children's learning and development. In a Piagetian perspective, play reflects one's level of cognitive development; whereas Vygotsky noted that play has the ability to propel a child forward in terms of cognitive development (Saracho \& Spodek, 1995). As Vygotsky (1978) emphatically posited, "play creates a zone of proximal development in a child. . . [It] contains all developmental tendencies in a condensed form and is itself a major source of development" (p. 102). These theories frame the present study and underlie the theoretical foundation by providing a benchmark against the issues of teaching and learning identified through the findings.

The Malaysian ECCE encounters several challenges in service delivery and implementation. According to PEMANDU (2013), most preschool teachers from the private sector had not undergone any formal training. In response to this, the Malaysian Government has established in the education blueprint that all preschool teachers should possess a minimum requirement of Diploma in Early Childhood Education by 2020 in efforts to improve the standards of preschool education (Ministry of Education, 2013).

In addition, $\mathrm{Ng}$ (2010) pointed out that there is bound to be a certain degree of mismatch between the planned ideals as established in the NPSC and the implemented reality. The extent to which the philosophies posited by the NPSC is implemented in actual practice remains uncertain. Moreover, the lack of coherence in the field of early childhood education could be a barrier toward ensuring quality ECCE in the nation.

In direct contradiction with the national preschool curriculum, a myriad of research evidence indicate that formal learning is still used as the main mode of teaching in many early childhood programmes across the nation (Ali, Aziz, \& Majzub, 2011; Ali \& Mahamod, 2015; Chen \& Chong, 2014; Ng \& Yeo, 2014; Abu Bakar, 2009; Abu Bakar et al., 2015; Majzub, 2013; Puteh \& Ali, 2013). This implies that large numbers of young Malaysian pre-schoolers in private settings still learn in traditional, structured classrooms where academic and rote learning take up most of the daily preschool routine. This contradicts with the ideal teaching and learning approach for young children, which should constitute active exploration in a conducive environment where learners are actively engaged in hands-on playful learning activities and develop holistically.

Early education is crucial as it serves as a head start that strongly impacts a child's future prospects. We should strive towards preparing and equipping our children well to meet challenges of the $21^{\text {st }}$ century. Considering these, there is certainly more room for improvement in the quality of the Malaysian early childhood education. However, the basis for improvement should be based on solid evidence of the current research context. This research study contributes to the literature in the area of preschool teaching and learning in the context of private Malaysian preschools catered for children aged four to six in the Klang Valley.

\section{METHOD}

This study employed a "basic qualitative research" which is the most common form of qualitative research in education (Merriam, 2009, p. 22). It sought to understand the issues pertaining to teaching and learning through perspectives of three teachers in Malaysian private preschools.

Three Malaysian female preschool teachers from three different private settings around the Klang Valley were purposefully selected. The participants were selected based on the criteria that they should be in-service, main teachers of preschools in the Klang Valley catering for young children of four to six, have at least two years of teaching experience in the field of preschool education, and willing to participate in the study by providing indepth and honest perspectives as teachers pertaining to the teaching and learning process of their respective settings. 


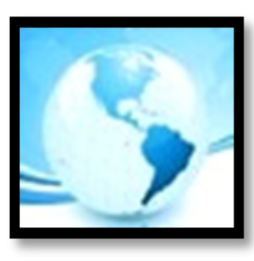

\section{MALAYSIAN ONLINE JOURNAL OF EDUCATIONAL MANAGEMENT (MOJEM)}

In addition, the "maximum variation" sampling technique (Merriam, 2009, p. 229) was used in selecting the participants for this present study, which enhanced the reliability and validity of the findings. Participants represented three different regions in the Klang Valley with different levels of qualification, as well as three types of preschool with varying philosophies as perceived by the participants. This heterogeneity of participants allowed findings to be applied by a greater range of audience. The demographic information of each participant is outlined in Table 1.

Table 1

Demographic Information of Participants

\begin{tabular}{ccccc}
\hline Participant & Age & $\begin{array}{c}\text { Years of } \\
\text { experience }\end{array}$ & Highest qualification & $\begin{array}{c}\text { Philosophy of affiliated } \\
\text { preschool }\end{array}$ \\
\hline $\mathbf{1}$ & 51 & 6 & SPM & Academic \\
\hline $\mathbf{2}$ & 27 & 7 & $\begin{array}{c}\text { Bachelor's Degree in Early Years } \\
\text { Education }\end{array}$ & Thematic \\
\hline $\mathbf{3}$ & 25 & 3 & Diploma in Early Years Education & Play-based creative learning \\
\hline
\end{tabular}

Selection of sample included ensuring that objective of research was thoroughly made known to the participants prior to data collection. With the confirmation of sample selection, consent was gained from the participants. Data was collected in the form of structured questions via open-ended interviews. The interview consisted of two parts i.e., teacher's demographic information and 14 open-ended questions eliciting participants' perspectives on preschool teaching and learning. The questions included philosophy of the setting and how far it is implemented in actual practice, the role of teacher and problems encountered in teaching and learning, opportunities provided for hands-on participation and play, degree of structure in the classroom, and pre-school's learning content. Openended questions were used for the interviews due to its appropriateness to better capture participants' perspectives and experiences in their engagement of teaching and learning in greater depth and richness; as well as increasing the likelihood for more elaboration from the participants as compared to survey questions with closed questions with standard answers or responses represented by Likert scale.

Prior to data collection, the interview protocol was validated by an expert of qualitative research to ensure its validity and reliability. Appropriate changes were made to the interview questions including sentence restructuring, elimination of jargons, abstract terms and multiple questions. Participants were encouraged to be as detailed and honest in responding to the questions.

By collecting qualitative data online, participants' emotions and body language will most likely be neglected. Moreover, data collected might not be as rich as face-to-face interviews. In order to address these limitations, observation was carried out in a suburban private preschool classroom in the Klang Valley to triangulate the data gathered from the interviews. Hence, two-method triangulation was applied in order to strengthen the validity of the findings. This is in accordance to the definition of triangulation by Kopinak (1999) which emphasised the use of more than one method to study a specific condition.

The observation site was selected due to its nature of academic and structured curriculum with limited time for play, which is in contradiction with the requirements of the national curriculum. It is a religious-based, non-profit preschool established back in 1958 for the purpose of providing preschool education for the underprivileged community of the area. This led to the researchers' motivation to study and explore its issues in teaching and learning through first-hand observation, which enabled authentic data to be collected on-site. 


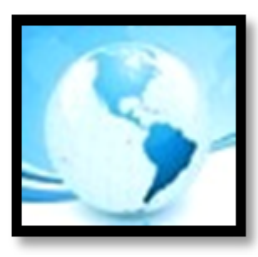

\section{MALAYSIAN ONLINE JOURNAL OF EDUCATIONAL MANAGEMENT (MOJEM)}

During the observation, the stance of the researcher was that of "observer as participant" with no direct involvement with the participants involved (Merriam, 2009). Detailed field notes were recorded by researcher as the observation took place. They were systematically arranged, refined and elaborated immediately after the observation to retain as many observed information as possible.

Following data collection, data collected was transcribed prior to qualitative thematic analysis. The analysis process of the collected data began by open coding. The responses collected from each participant were critically read, examined and the initial codes were then formulated. The same process was repeated for the observation data. This was followed by axial coding and selective coding, as suggested by Strauss and Corbin (1998) pertaining to qualitative data analysis. As patterns started emerging from the data, two analysis matrices were built--- one for each data source. The researcher then began to compare and combine similar codes from both the interview and observation data as appropriate. The grouping and organization of the codes led to the emergence of subthemes.

Finally, as similar patterns within the subthemes were discerned, they were subsequently categorised, leading to themes for the study. As suggested by Merriam (2009), "peer examination" (p. 229) was conducted in the process of data analysis. This was done through in-depth discussions with colleagues regarding the formation of codes and acquisition of themes from the data collected to ensure its credibility and trustworthiness, hence enhancing the reliability and validity of the study.

\section{RESULTS}

Following data analysis, data regarding issues on teaching and learning in the preschool classroom were classified and structured into four umbrella themes: a) Role of the teacher, b) curricular orientation, c) curricular flexibility and d) philosophical dilemma. In each theme, two subthemes were identified and will be elaborated respectively in the following. Having umbrella themes establishes a systematic structure for the subthemes and enables easier understanding and better clarity in presenting the findings. Moreover, clear patterns and relationships between the subthemes could be captured and illustrated; which emphasised the interrelation of the subthemes as well as the themes with the topic of research. Excerpts from the data, including interview transcripts as well as first-hand observation field notes will be used to support and elaborate each theme to illustrate the issues present in the preschool teaching and learning process.

\section{Role of the Teacher}

Data gathered implied that teachers held excessive control in the preschool classroom. This resulted in the lack of opportunities for pre-schoolers to express themselves in the classroom due to the "dictatorship" of the teachers.

It also revealed the excessively teacher-centred and teacher-dependent nature of the preschool settings, which will be discussed in depth through two different themes as follows which include, 1) little allowance for children's expression; and 2) teacher's role as an instructor.

\section{- Little allowance for children's expression}

Findings from the observation indicated that lessons conducted were highly structured and had little allowance for the children to express themselves whether through verbal or non-verbal means. This concurred with one of the participants who claimed,

"During lesson time, (there is) high teacher's control over the children. During free time, children are allowed to enjoy their social interaction and quiet time with teacher supervision" (13: L9-10) 


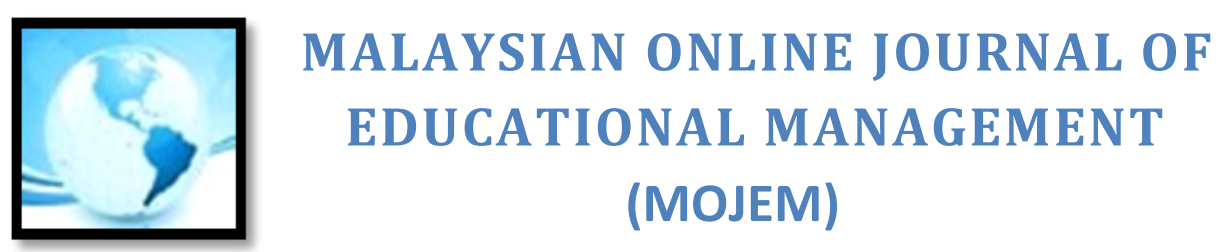

This implied that lessons were considered structured and formal which should be under complete control by the teacher.

Moreover, instead of open-ended questions to stimulate and encourage children's communication, formal and closed questions were observed to be used extensively by teachers in the preschool classroom. This is supported by the excerpt from the observation field notes below:

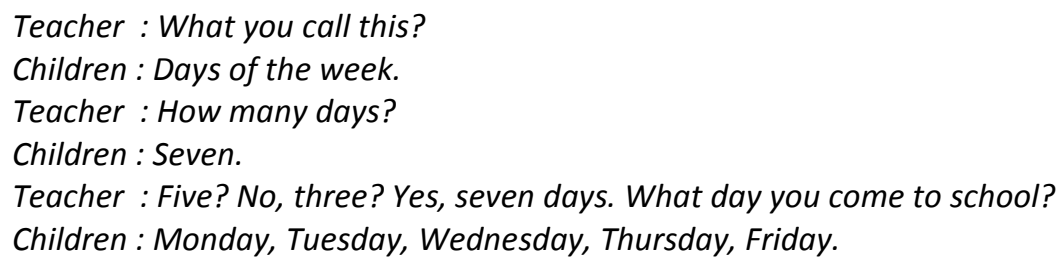

(01: L66-71)

Hence, due to the teacher-centred approach of preschool teaching and learning, little evidence of children's rich and creative expressions was found in practice.

\section{- Teacher's role as an instructor}

Findings suggested that there was high teacher control over the preschool classroom, especially on children. This resulted in little freedom of choice for children, as the pre-schoolers were expected to follow teachers' instructions at all times. A participant explained the approach used in her classroom:

It's teacher-led most of the time as they (children) need to get used to accepting instructions and follow the rules that are given like 'keep your hands to yourself' so they won't disturb their friends or touch anything yet without instruction; 'listening ears' to make sure they listen during the lesson. (12: L17-21)

Another participant indicated the extent to which teachers are in control of everything in the preschool setting: "Most of the time, teacher tells or explains, children follow and do what teacher says" (I3: L13-14) .

During the observation session, the researcher discerned that the teacher in-charge was constantly giving instructions to children in a period of 45 minutes as recorded in the observation fieldnotes below. In response to these instructions, children were seen to be obliged to comply to ample restrictions in a highly teacher-centred classroom with little freedom and control over their own learning process.

Teacher: FASTER DRINK WATER! (in a loud voice)

Teacher: I want all of you take pencil, take now.

Teacher: All of you look at the book! Don't look at my face!

Teacher: I want all of you to stand up. Stand straight!

Teacher: Sit straight, listen properly and read!

(01: L85-90) 


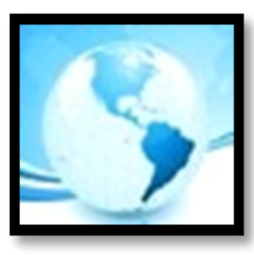

\section{Curricular Orientation}

Data collected also reflected the issue on the curricular orientation of preschool settings. Upon data analysis, the researcher discerned that preschool classrooms were heavily inclined towards academic mastery and preparation for formal education. Two subthemes that emerged from the triangulated data are: 1) excess priority on educational goals, and 2) premature emphasis on literacy.

\section{- Excess priority on educational goals}

A heavy emphasis on academic readiness was generally discerned based on the findings. Every strategy used was largely skewed towards academic outcomes. Observation conducted reiterated that lessons were heavily related to subject-based content with heavy reliance on books, with the purpose to achieve purely academic outcomes. Other essential skills such as creativity, innovation, moral values, or aesthetic skills seemed to be neglected in the context of study. As one participant aptly described:

"We use various teaching aids to help the kids to learn. We have a technology tool called smartboard that allow the children to play some games to do revision on their studies; exercise books, workbook and text books to learn different subjects like English, Malay, Mandarin and Math; Science equipment to do different experiments with the kids to learn Science; educational games to help improve learning on the main subjects; word cards to learn English and Malay; and apparatus to help improve main subjects too"(12: L24-32).

\section{- Premature emphasis on literacy}

In addition, there seemed to be a premature focus on literacy in the Malaysian preschool classroom. Children were expected to have good reading and writing competencies. Drilling, rote reading and writing on workbooks were observed to remain a norm in the teaching and learning of preschool settings. During the observation session, children were observed to read after the teacher as she wrote the day and date on the whiteboard. The students then spelt each word on the board and then stood up one by one to 'recite' the alphabet written on the board. The teacher was observed saying to the children:

"Every day when you go back you have to read. Because you have to recognise the word (writes $B A B Y$ on the board). What word is this? (Some children read the word) Baby! Because B-A-B-Y. Next, we are going to read "days of the week"(01: L58-61).

This premature push for literacy has led to problems in pre-school's learning, as emphatically pointed out by several participants:

"Children can read and write but lack understanding as teachers have to finish the syllabus set for each term. Thus, there is not enough time given for fun and hands-on activities that will help children to understand what they are studying "(I1: L6-8).

"I don't think worksheets are effective. I realise that most of the children do not know the concept about the worksheets they did and have poor reading skills"(I3: L50-52).

"There is insufficient time for slower children to learn and teacher to teach them or help them revise"(12: L62). 


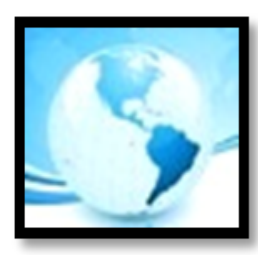

\section{MALAYSIAN ONLINE JOURNAL OF EDUCATIONAL MANAGEMENT (MOJEM)}

Observation data showed that pre-schoolers who could not read were scolded (O1: L30, 97) and even punished by standing (01: L106) by the teacher. This premature emphasis on reading may have caused unrealistic expectations that are inappropriate according to children's development and individual levels.

\section{Curricular Flexibility}

Considering the development of pre-schoolers which is dynamic and fluid, the preschool curriculum should ideally reflect a certain degree of fluidity to cater to children's varying dispositions in learning. Nevertheless, findings from this present study indicated little flexibility in the preschool curriculum. This can be illustrated through the subthemes of 1) subject-based curriculum, and 2) excessive structure in the classroom.

\section{- Subject-based curriculum}

All three participants stated that the preschool curriculum in their respective settings is conventionally structured based on subjects:

"Children have to learn language (English and BM), Mathematics, Cultural, Science, Moral, Art and craft..."(11: L26-27).

"In my preschool, children learn the main stream subjects like Language (BM, English), Mathematics, Science, Art and Craft and Moral "(I3: L28-29).

"Children learn different subjects such as Mandarin, Malay, English-- like blends, vocabulary and literature, Math, and Science "(I2: L34-35).

Similarly, through observation, the children were seen to be having an English lesson, where they were required to recite the alphabet and then days of the week, before reading page by page from their textbook. Children's learning content were found to be rigidly encapsulated in traditional subjects with predetermined learning outcomes. This implies a lack of awareness and implementation of an integrated and holistic preschool curriculum, as opposed to the requirements established in the national preschool curriculum. This reflected and contributed to the rigidity of the preschool classroom as a whole.

\section{- Excessive structure in the classroom}

Several aspects including the classroom setting, routines and the teaching and learning process pointed to the formal and structured approach used in the preschool settings. At the observation setting, five-year-old children sat down with their school bags and pencil cases at tables arranged into rolls. Figure 1 illustrates the observed layout of the classroom for five-year-old pre-schoolers in the observation site. 


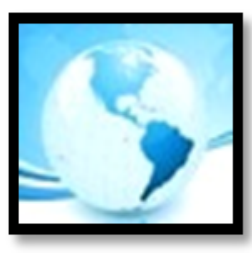

MALAYSIAN ONLINE JOURNAL OF

EDUCATIONAL MANAGEMENT

(MOJEM)

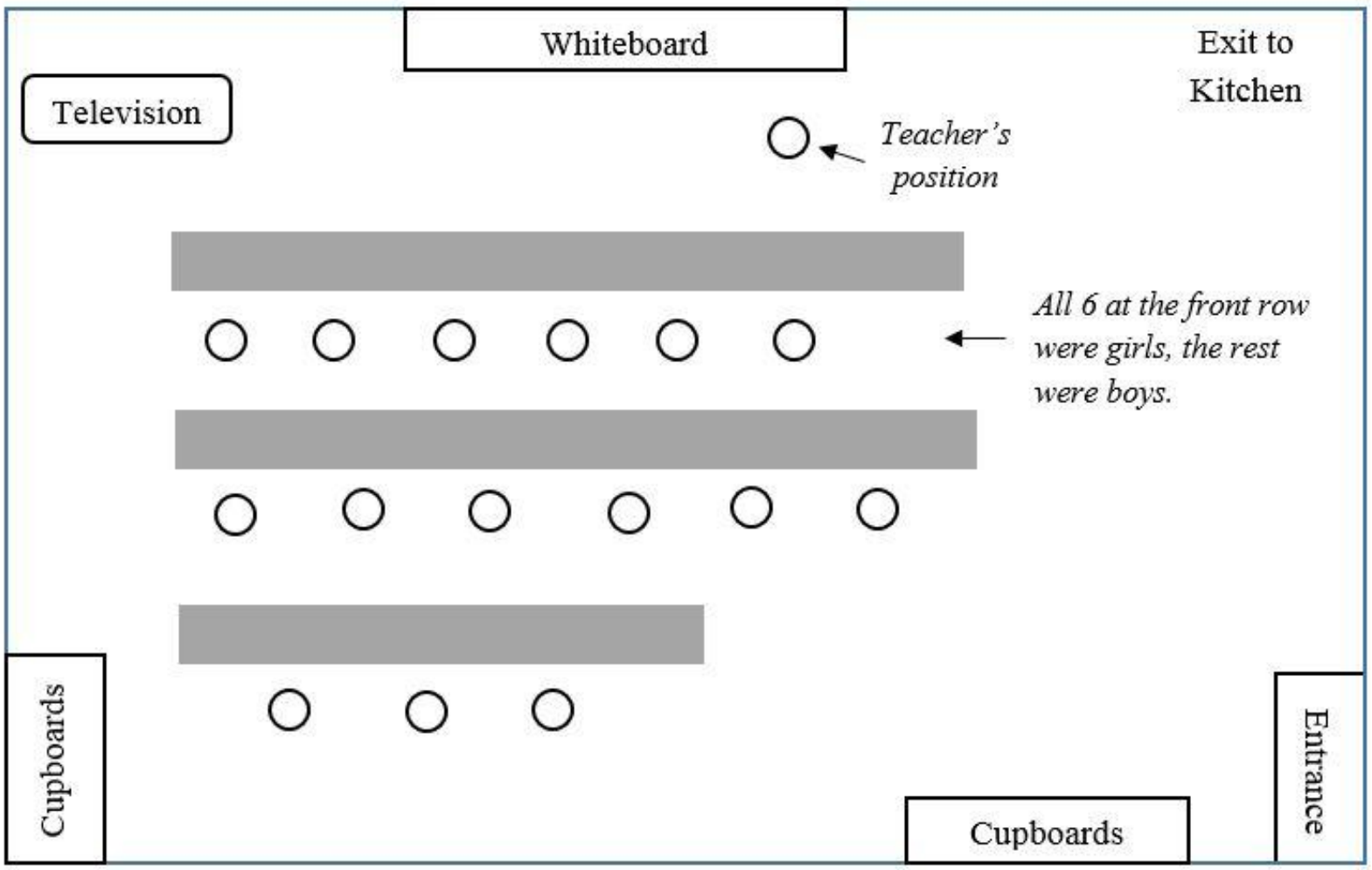

Figure 1. The observed classroom layout.

As required by the teacher, the pre-schoolers opened their textbooks and started reading page by page. Formal routines similar to primary schools' setting were practiced such as standing to greet the teacher formally (O1: L2123). Participants' responses also reiterated the formal, structured manner during classroom teaching and learning. One participant particularly drew attention to how preschool children learn in a traditional approach where they are "required to sit in the class most of the time to learn" (I2: L10).

Other responses similarly suggested the highly structured preschool teaching and learning:

"We use theme-based system in my preschool. But with the mixture of academic it has become too rigid. The schedule has become too tight or pack that teacher is rushing through the syllabus"(12: L8-9).

"Teachers have to finish the syllabus set for each term. All workbooks are set for every subject and there are lots of workbooks to complete for each term "(I1: L6-7).

"A lot of worksheets await. There are no concrete teaching aids provided and the learning environment does not support active learning (even teaching) due to space constraint and no outdoor space available "(I3: L33-34). 


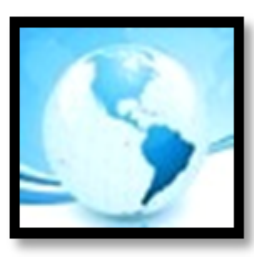

\section{MALAYSIAN ONLINE JOURNAL OF EDUCATIONAL MANAGEMENT (MOJEM)}

\section{Philosophical Dilemma}

One of the key issues identified in this study included the "power struggle" teachers face in terms of the philosophy or teaching approach they should apply in their preschool classroom. Subthemes that were formulated include 1) mismatch between ideal and reality, and 2) mismatch between teachers' beliefs and practice.

\section{- Mismatch between ideal and reality}

Two participants explicitly pointed out discrepancies between the planned philosophy or the ideal and how far it has been implemented in practice:

"The current school that I am serving is promoting play-based (creative) learning. Sad to say, no play-based teaching and learning is practiced in the school other than paper and pencil work (academic) "(13: L3-8).

"There are too many subjects to be taught to such young children. The teaching and learning process should be centred on the child's early development "(I1: L45-47).

Observation data reinforced this subtheme as the approaches seen conducted in the classroom are in little accordance to what was laid out in the national preschool curriculum NPCS, nor did it represent the ideals reflecting effective practice for early childhood education. In contrast to fun, meaningful play-based activities, preschoolers were found to be seated in the classroom most of the time; being taught one subject after another, instead of discovering and learning for themselves.

\section{- Mismatch between teachers' beliefs and practice}

Most preschool teachers realized the problems in practice and suggested better strategies of improving teaching and learning in their respective settings. However, they are restrained by obligations to follow the set standards to teach as required by the preschool management. Two participants expressed their opinions as follows:

"Worksheets-based learning is not effective at all... But based on the centre's practice and lessons, I'm practicing teacher-centred approach and more to formal learning. Most of the time, lessons are done based on the requirement of worksheets" (I3: L14-20).

"I use formal approach as the children are being taught to get ready for Chinese school and therefore I have been requested to be firm with the kids" (I2: L16-17).

\section{DISCUSSION AND IMPLICATIONS}

The findings above provided a glimpse into the actual practice of the teaching and learning in several private preschool settings in Klang Valley, Malaysia. It shows that there are several implementation gaps in the Malaysian preschool education and thereby pointed out the areas which require urgent revamp and improvement. The results concurred with several research studies which posited that formal and didactic approaches remain the main mode of the teaching and learning approach in Malaysian preschools (e.g. Ali \& Mahamod, 2015; Chen \& Chong, 2014; Ng \& Yeo, 2014). Lerkkanen et al. (2016) affirmed the significance of child-initiated practices in preschool education in improving academic outcomes of children's later grades. Despite the fact that child-centred learning where children participate actively in their own process of learning is known to be effective in early childhood education, this is apparently not being practised in most Malaysian private preschool settings. 


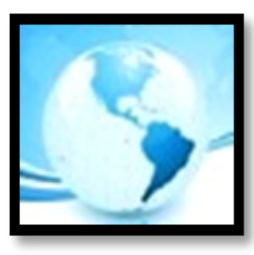

\section{MALAYSIAN ONLINE JOURNAL OF EDUCATIONAL MANAGEMENT (MOJEM)}

As reflected by the issues identified in this study, the current teaching and learning practices in Malaysian private preschools are incongruent with developmentally appropriate practice (DAP) which outlines the best practices established by the National Association for the Education of Young Children (NAEYC, 2009) that should be practised in every early childhood setting. First, the role of a preschool teacher should ideally be as a facilitator to support children's development, instead of an instructor who dictates and holds ultimate control over children's actions (Nielsen, 2006). Nor should a preschool teacher equate a technician whose job is merely to transmit prescribed content to the learners (Takaya, 2008). At the same time, children should be given some degree of control and involvement in the preschool classroom. This includes making choices pertaining to their own learning and the freedom to express their thoughts and emotions openly. A teacher should be cautious to strike a balance between being in complete control and to empower children with a certain degree of control.

Next, rather than focusing excessively on academic abilities especially literacy and numeracy, more emphasis should be placed on developmental milestones such as physical and socio-emotional development which are more significant to laying a firm foundation for children's later development. Moreover, the preschool curriculum should be less structured to cater to a larger range of children's learning dispositions.

The incongruities of preschool practice with the recommended ideal practice might be justified by the philosophical dilemmas preschool teachers are stuck in. This parallels with $\mathrm{Ng}(2010)$ who pointed out that there is bound to be a certain degree of mismatch between the planned ideals as established in the Malaysian preschool curriculum and the implemented reality. External factors such as parental expectations for children to be prepared for primary school; and limited resources or outdoor space might be additional contributing factors to a structured and formal preschool curriculum. Another factor that is less acknowledged is teachers' obligations to adhere to the philosophy set by the preschool management. These factors should be considered carefully to enable an improved preschool education that promotes the holistic development of all Malaysian pre-schoolers.

In light of the issues discussed, much has to be done to ensure that Malaysian children are provided with a head start of a better quality early education. The first and foremost step includes monitoring and raising teachers' qualifications in private preschools, as quality teachers are key determinants of a successful education system. One of the most crucial, yet unaddressed problems within the Malaysian early childhood sector is the unmonitored employment of teachers. According to the Malaysian Performance Management and Delivery Unit, also known as PEMANDU (2013), an estimated percentage as high as $93 \%$ of preschool teachers have not received any formal training. Most of these teachers are from the private sector. Therefore, there should be a specific body that rigorously monitors the teachers. Alongside that, the organization would also ensures and assess all teachers, whether they are from public or private preschool settings are adequately equipped with knowledge of child development and competencies to teach young children with developmentally appropriate strategies. This organization should also provide continuous support to preschool teachers to implement developmentally appropriate practices in the preschool settings to benefit pre-schoolers of the nation. The improvement in preschool teachers' quality will then lay the foundation of the transformation of the Malaysian early childhood education.

Next, there should be a paradigmatic shift in the societal belief towards success prior to a change in the accustomed approach in preschool teaching and learning. Most Malaysians define success solely by academic achievement. Thus, a majority of Malaysian parents expect pre-schoolers to master the 3R's (writing, reading and arithmetic) in the preschool setting in order for them to be prepared for primary schooling (Curriculum Development Centre, 2007; Abu Bakar et al., 2015). This premature emphasis on academic achievement in Malaysian preschools resulted in the poor implementation of active learning and play-based approach, despite these being known as the effective mediums for young children's development. This misconception might be the underlying reason behind the excessive teacher-centred curriculum, little curriculum flexibility, academic-oriented and the philosophical discrepancy between ideal and reality. 


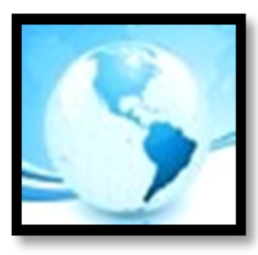

\section{MALAYSIAN ONLINE JOURNAL OF EDUCATIONAL MANAGEMENT (MOJEM)}

Therefore, awareness should be raised in order to initiate an in-depth transformation pertaining to the conventional or cultural assumption which places great and unrealistic value upon academic excellence. Only through this could the Malaysian early childhood education successfully head towards an improved and more effective service provision.

Meanwhile, it is important to note that the findings of this study were based only on three research participants from private preschool settings in the Klang Valley, Malaysia. In addition, each Malaysian preschool from the private sector differs in terms of management, philosophy, teachers' qualifications and sociocultural context. Hence, the findings are context-specific and might not represent the respective situation in other Malaysian preschools including public settings and preschools outside the Klang Valley.

Nevertheless, findings from this study could undeniably represent and reflect the issues present in terms of teaching and learning of private preschools. They could also spur further research to explore the in-depth factors that may lead to these issues, hence subsequently formulate practical solutions towards enhancing the quality of our preschool education.

\section{CONCLUSION}

Findings from this present study indicated that the role of teachers in several Malaysian private preschools supersedes and jeopardises pre-schooler's control over their own learning. Contradicting to the holistic development advocated by the national preschool curriculum, there is an apparent emphasis on educational outcomes and literacy in highly structured and formal preschool environments. There should be more fluidity in the Malaysian preschool curriculum to cater for a variety of pre-schooler's needs, dispositions and different sociocultural contexts in each preschool setting through active learning. In addition, there is a need for rigorous measures to bridge the gap between the rhetoric and reality in preschool teaching and learning. Figure 2 presents a summary of the issues established through this present study to advance toward an improved preschool education in Malaysia. In order to bring about a more effective preschool education that would greatly benefit all Malaysian pre-schoolers, it is incumbent for the relevant authorities to seriously look into and tackle each of these issues identified appropriately.

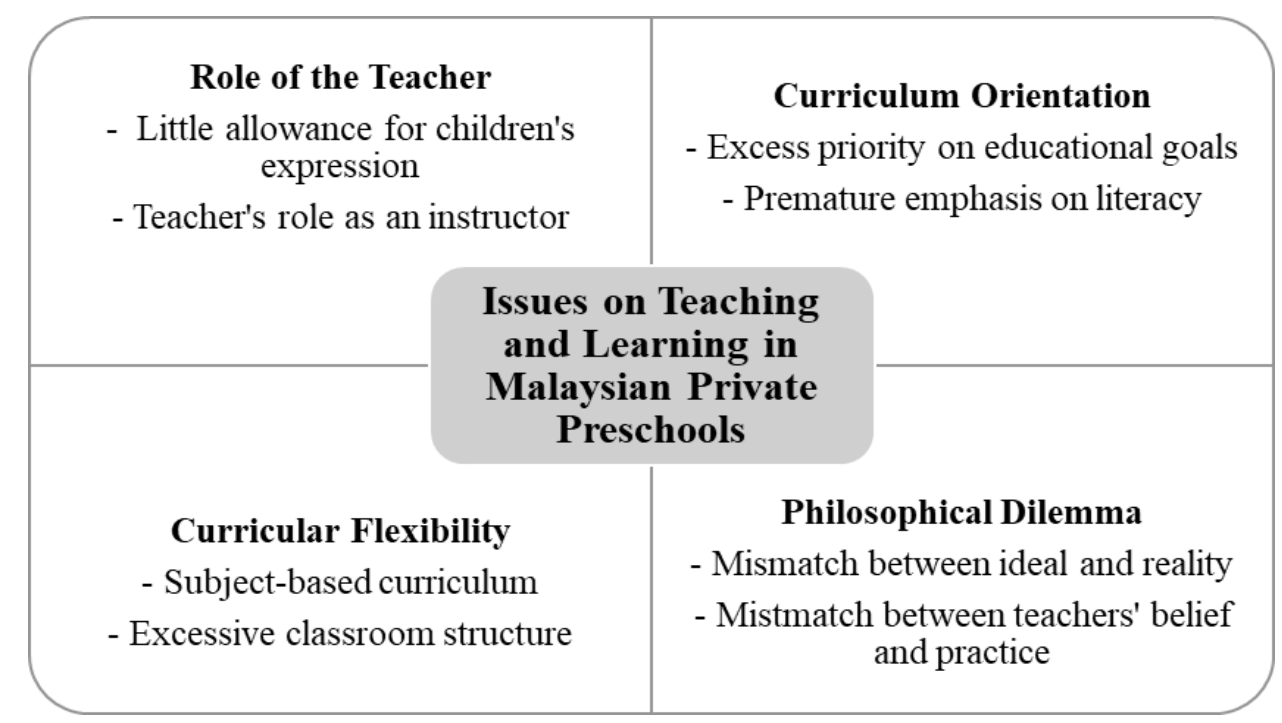

Figure 2. Summary of the findings in this present study. 
Since private preschools are largely driven by parental demands and expectations, future research directions could include exploring how parents perceive the current teaching and learning in preschools. Another possible study that could be conducted is a quantitative study with larger and more representative samples including both the public and private preschool settings; in order to provide an overview of the Malaysian preschool education which remains fragmented and needs further revamping. In-depth exploration of the factors behind these identified issues as well as development of empirically tested instructional materials would lead to greater contribution toward the continual efforts to improve and revamp the Malaysian preschool teaching and learning.

\section{REFERENCES}

Abu Bakar, N. (2009). A study of approaches used by early childhood education teachers in Malaysia. Paper presented at the London International Conference on Education (LICE), London, United Kingdom. Retrieved from http://research.gold.ac.uk/6571/1/LICE-2009_Proceedings.pdf

Abu Bakar, N., Daud, N., Nordin, N. \& Abdullah, A. H. (2015). Developing integrated pedagogical approaches in play pedagogy: Malaysian experiences. Asian Social Science, 11(4), 234-245. doi: 10.5539/ass.v11n4p234

Ali, A., Aziz, Z., \& Majzub, R. (2011). Teaching and learning reading through play. World Applied Sciences Journal, 14, 15-20. Retrieved from http://idosi.org/wasj/wasj14(LIDDL)11/3.pdf

Ali, A. \& Mahamod, Z. (2015). Needs analysis on module users of play-based language instructional module] Needs analysis on user-specific target-based module-based approaches for teaching and learning preschool children's skills (In Malay). Journal of Asian-Pacific Curriculum \& Teaching, 3(1), 1-8. Retrieved from http://juku.um.edu.my/filebank/published_article/7232/Artikel_1_Bil_3_Isu_1.pdf

Chen, L. W., \& Chong, S. C. (2014). The compatibility of intelligence and learning styles: A case study among Malaysian preschoolers. Australian Journal of Basic \& Applied Sciences, 8(5), 144-150. Retrieved from http://ajbasweb.com/old/ajbas/2014/Special\%202/144-150.pdf

Cheng, D. P. W. (2012). The relation between early childhood teachers' conceptualization of "play" and their practice: Implication for the process of learning to teach. Frontiers of Education in China, 7(1), 65-84. doi: 10.3868/s110-001-012-0004-2

Curriculum Development Centre. (2007). Kajian Pelaksanaan Kurikulum Prasekolah Kebangsaan [National Preschool Curriculum Implementation Study]. Putrajaya: Ministry of Education.

Curriculum Development Centre. (2008). Early childhood care and education policy implementation review. Putrajaya: Ministry of Education.

$\begin{array}{llll}\text { Education } & \text { Act } & \text { (2006). } & \text { Retrieved from }\end{array}$ http://planipolis.iiep.unesco.org/upload/Malaysia/Malaysia_Education_Act_1996.pdf

Fisher, K. R., Hirsh-Pasek, K., Golinkoff, R. M., \& Gryfe, S. G. (2008). Conceptual split? Parents' and experts' perceptions of play in the 21st century. Journal of Applied Developmental Psychology, 29(4), 305-316. doi: 10.1016/j.appdev.2008.04.006 


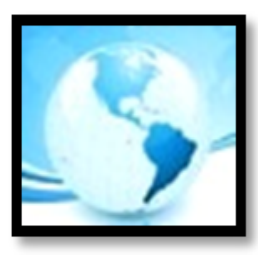

Huisman, S., Catapano, S., Moody, A. K., \& Gates, L. K. (2013). Families' perception on play in the early childhood setting. Journal of Psychological and Educational Research, 21(1), 28-48. Retrieved from http://search.proquest.com/docview/1404746730?accountid=28930

Kopinak, J. K. (1999). The use of triangulation in a study of refugee well-being. Quality and Quantity, 33(2), 169183. doi: $10.1023 / \mathrm{A}: 1026447822732$

Kuschner, D. (2012). Play is natural to childhood but school is not: The problem of integrating play into the curriculum. International Journal of Play, 1(3), 242-249. doi: 10.1080/21594937.2012.735803

Lerkkanen, M.-K., Kiuru, N., Pakarinen, E., Poikkeus, A.-M., Rasku-Puttonen, H., Siekkinen, M., \& Nurmi, J.-E. (2016). Child-centered versus teacher-directed teaching practices: Associations with the development of academic skills in the first grade at school. Early Childhood Research Quarterly, 36 (3rd Quarter), 145-156. doi:http://dx.doi.org/10.1016/j.ecresq.2015.12.023

Loizou, E., \& Avgitidou, S. (2014). The Greek-Cypriot early childhood educational reform: Introducing play as a participatory learning process and as children's right. Early Child Development and Care, 184(12), 18841901. doi: 10.1080/03004430.2014.892482

Majzub, R. M. (2013). Critical issues in preschool education in Malaysia. Paper presented at the 4th International Conference on Education and Educational Technologies, Cambridge, USA. Retrieved from http://www.wseas.us/e-library/conferences/2013/CambridgeUSA/EET/EET-26.pdf

Merriam, S. B. (2009). Qualitative research: A guide to design and implementation. San Francisco, CA: Jossey-Bass.

Milteer, R. M., \& Ginsburg, K. R. (2012). The importance of play in promoting healthy child development and maintaining strong parent-child bond: focus on children in poverty. Pediatrics, 129(1), 204-213. doi: 10.1542/peds.2011-2953

Ministry of Education. (2013). Malaysia education blueprint 2013 - 2025 (Preschool to post-secondary education). Putrajaya: Kementerian Pendidikan Malaysia.

Ministry of Education. (2017). Kurikulum standard prasekolah kebangsaan [National Preschool Standard Curriculum]. Putrajaya: Kementerian Pendidikan Malaysia.

National Association for the Education of Young Children. (2009). Developmentally appropriate practice in early childhood programs serving children from birth through age 8. Washington, DC: NAEYC.

Ng, P. F., \& Yeo, K. J. (2014). Preschool teachers' beliefs and practices on early literacy instruction. Sains Humanika, 2(4), 139-146. Retrieved from http://www.sainshumanika.utm.my/index.php/sainshumanika/article/download/481/436

$\mathrm{Ng}$, S. B. (2010). Governance of education related ECCE policies in Malaysia. International Journal of Child Care and Education Policy, 4(1), 45-57. doi:10.1007/2288-6729-4-1-45.

Nicolopoulou, A. (2010). The alarming disappearance of play from early childhood education. Human Development, 53(1), 1-4. doi: 10.1159/000268135. 


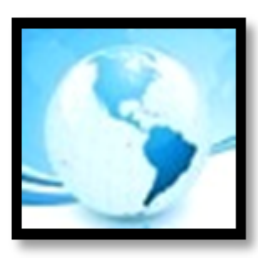

Nicolopoulou, A., Barbosa de Sá, A., Ilgaz, H., \& Brockmeyer, C. (2009). Using the transformative power of play to educate hearts and minds: From Vygotsky to Vivian Paley and beyond. Mind, Culture, and Activity, 17(1), 42-58. doi: 10.1080/10749030903312512.

Nielsen, D. M. (2006). Teaching young children: A guide to planning your curriculum, teaching through learning centers, and just about everything else. Thousand Oaks, CA: Corwin Press.

PEMANDU. (2013). Economic Transformation Programme: Annual report 2013. Retrieved from http://etp.pemandu.gov.my/annualreport2013/

PEMANDU. (2015). Government Transformation Programme: 2014 annual report. Retrieved from http://www.pemandu.gov.my/gtp/upload/Eng GTP2014 AR Full.pdf

Puteh, S. N., \& Ali, A. (2013). Preschool teachers' perceptions towards the use of play-based approach in language and literacy development for preschool. Malaysian Journal of Learning and Instruction, 10, 79-98. Retrieved from http://www.ukm.my/jpbm/pdf/141-159\%20Sharifah\%20Nor\%20\&\%20Aliza.pdf

Samuelsson, I. P., \& Carlsson, M. A. (2008). The playing learning child: Towards a pedagogy of early childhood. Scandinavian Journal of Educational Research, 52(6), 623-641. doi: 10.1080/00313830802497265.

Sandberg, A., \& Heden, R. (2011). Play's importance in school. Education 3-13, 39(3), 317-329. doi: $10.1080 / 03004270903530441$.

Saracho, O. N., \& Spodek, B. (1995). Children's play and early childhood education: Insights from history and theory. Journal of Education, 177(3), 129-148. Retrieved from http://search.ebscohost.com/login.aspx?direct=true\&db=pbh\&AN=9705281799\&site=eds-live

Strauss, A., \& Corbin, J. M. (1998). Basics of qualitative research: Techniques and procedures for developing grounded theory. Thousand Oaks, CA: SAGE Publications.

Takaya, K. (2008). Jerome Bruner's theory of education: From early Bruner to later Bruner. Interchange, 39(1), 119. doi: 10.1007/s10780-008-9039-2.

UNICEF. (2011). National conference on early childhood care and education. Retrieved from http://www.eccemy.com/booklet.pdf

Van Oers, B., \& Duijkers, D. (2013). Teaching in a play-based curriculum: Theory, practice and evidence of developmental education for young children. Journal of Curriculum Studies, 45(4), 511-534. doi: 10.1080/00220272.2011.637182.

Vygotsky, L. S. (1978). Mind in society: The development of higher psychological processes. Cambridge, MA: Harvard University Press.

Whitebread, D., Basilio, M., Kuvalja, M., \& Verma, M. (2012). The importance of play: A report on the value of children's play with a series of policy recommendations. Retrieved from http://www.importanceofplay.eu/IMG/pdf/dr_david_whitebread_-_the_importance_of_play.pdf 